\title{
Kó JÓZSEF
}

\section{Miért csökken a regisztrált büncselekmények száma?}

A hazai bűnügyi statisztika, az ENYÜBS adatai szerint a regisztrált büncselekmények száma látványosan csökkent az elmúlt néhány évben. A XX. század végi, a rendszerváltást követő időszak dinamikus emelkedése és a rekordokat döntő büncselekményi számok már a múlt homályába vesztek. Az eddigi legmagasabb, 600 621-es értéket 1998-ban jelezte a statisztika (1. számú ábra).

1. számú ábra

A regisztrált büncselekmények gyakoriságának alakulása

az ENYÜBS adatai szerint (1968-2017)

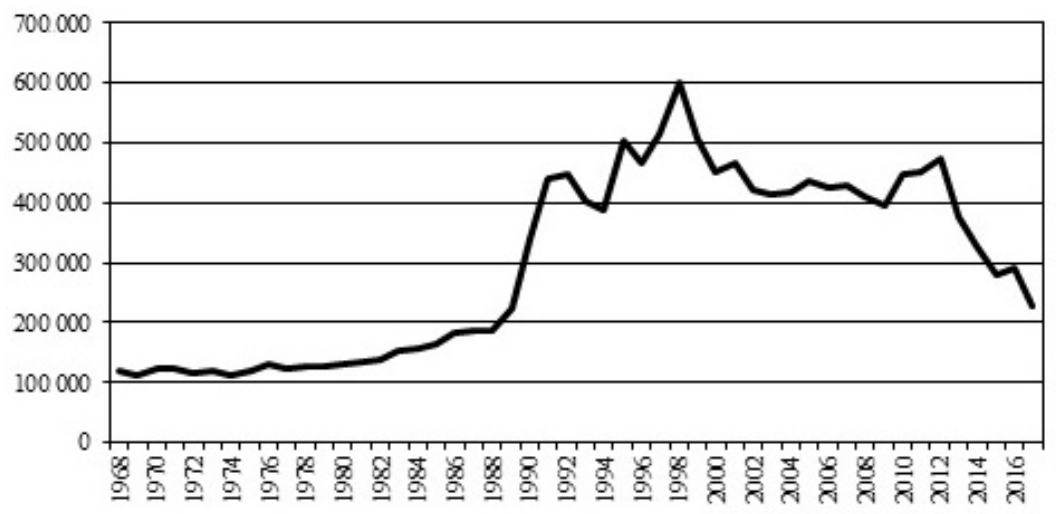

A rekord elérése utáni években az adatok gyors csökkenést mutattak, és az ezredforduló után az éves négyszázezer körüli értéken stabilizálódott a statisztikában megjelenő törvénysértések száma. 2009-ben már a négyszázezres határ alatt is járt az érték, majd újra emelkedő tendencia kezdődött, és 2012ben 472 236-os értékkel új XXI. századi csúcsot ért el.

Ez után azonban dinamikus csökkenés vette kezdetét. Előbb száz-, majd ötvenezerrel csökkent a regisztrált bünesetek száma, s 2017-re az 1989-es szintre mérséklődött az esetszám. A korábbi években jellemző négyszázezres gyakoriság helyett jelenleg már a kétszázezres értéket közelíti meg az esetszám.

Mi történt az utóbbi öt évben? Miért csökkennek ilyen drasztikusan a számok? 
Mielőtt ezekre a kérdésekre megpróbálnánk válaszolni, néhány dolgot mindenképpen tisztázni kell. A legfontosabb jellemzője a bünügyi statisztikának, amiről rendszeresen megfeledkeznek még a szakemberek is, és ami a laikusokat mindig megtéveszti, hogy a bünügyi statisztika nem tükrözi közvetlenül a tényleges bünözés alakulását. A bünözés egészében és a bünügyi statisztikában akár ellentétes irányú tendenciák is érvényesülhetnek azonos időben. A bünügyi statisztika emelkedő számértékei nem jelentik szükségképpen azt, hogy az elkövetett büncselekmények száma is nő. Elöfordulhat, hogy valóban így van, de a ténylegesen elkövetett törvénysértések száma akár csökkenhet is annak ellenére, hogy a statisztika növekvő értékeket mutat. Természetesen fordított helyzet is elöállhat.

A kriminológia-tankönyvek három tényezöt szoktak felsorolni, amelyek közvetlenül befolyásolják a bünügyi statisztika alakulását. Ezek a következők:

- feljelentési hajlandóság;

- jogszabályi környezet;

- nyomozó hatóságok preferenciái, attitüdje.

A diákok mindig meglepődnek, és reklamálnak, hogy nincs ott a befolyásoló tényezők között a bünözés tényleges alakulása. Nemzetközi tapasztalatok ${ }^{1}$ nyomán azt láthatjuk, hogy a viktimológiai felmérések alapján becsült és a statisztikákban megjelenő büncselekmények számának alakulása nem együtt mozog és nem feltétlenül azonos irányban változik.

\section{A lakosság és a szervezetek feljelentési hajlandósága}

Időnként hajlamosak vagyunk megfeledkezni arról, hogy a bünözés nem csak a magánembereket érinti. Az egy évben regisztrált büncselekmények sértettjeinek kb. negyven százaléka jogi személyiséggel felruházott szervezet. Bűncselekményeket gazdasági társaságok, intézmények, egyházak, nonprofit szervezetek stb. sérelmére is követnek el. Egy 2010-es uniós vizsgálat eredményei szerint Magyarországon minden negyedik gazdasági szervezet (25,7 százalék) vált büncselekmény sértettjévé a vizsgálatot megelőző tizenkét hónapban. ${ }^{2}$ Ebben a körben is jelentős látenciával kell számolnunk, mert példá-

\footnotetext{
1 Sajnos hazai adatokra nem lehet támaszkodni ezekben a kérdésekben, mert több, erről döntő kormányhatározat ellenére Magyarországon nincsenek rendszeres viktimológiai vizsgálatok, amelyek megerősíthetnék vagy cáfolhatnák a külföldi tapasztalatokat.

2 Marco Ducato (ed.): The crime against businesses in Europe: Pilot survey. 2010/ISEC/Pr/042-A2.
} 
ul a gazdasági társaságok sokszor, ha saját dolgozó követi el a törvénysértést, „házon belül”, fegyelmi eljárás keretében rendezik az ügyet, és nem fordulnak a hatóságokhoz. A vállalatoknak gyakran nem érdekük, hogy nyilvánosságra kerüljenek a velük kapcsolatban történt törvénysértések. A jó hírnév védelme érdekében sokszor inkább elviselik az esetleges veszteségeket, hogy elkerüljék az esetek kiderülését. Az intézmények esetében is megfigyelhetünk hasonló jelenséget. Az intézmény vezetői, attól való félelmükben, hogy rossz pontot szereznek a fenntartónál, inkább eltitkolják vagy próbálják saját hatáskörben megoldani a megtörtént eseteket. A jogi személyiségü sértettek esetében a cselekmények elszaporodása és a jelentősebb kárérték erősítheti a feljelentési hajlandóságot.

A lakosság feljelentési hajlandóságát is több tényező befolyásolja. A büncselekmény típusa fontos tényező. Általában az erőszakos cselekményeket gyakrabban jelentik a sértettek, de persze itt is vannak kivételek. Elöfordul, hogy a sértettet annyira megfélemlítik, hogy nem mer a rendőrséghez fordulni. Fontos szerepe van az elszenvedett kár mértékének. Minél nagyobb veszteség éri az illetőt, annál valószínübb, hogy a hatóságokhoz fordul. Például a gépjármülopásokat szinte mindig bejelentik.

A feljelentés-nem feljelentés kérdés eldöntésében döntő szerepük van a korábbi tapasztalatoknak, és az eljárás következményeiröl szerzett információnak. A kedvező tapasztalatok nyilvánvalóan növelik a feljelentés valószínủségét. Ha az eljárás során, illetve az eljárás eredményeképpen nem a sértett előzetes elvárásainak megfelelően történnek az események, akkor a kedvezőtlen tapasztalatok csökkentik a feljelentési hajlandóságot. A vagyon elleni cselekményeknél a sértettek elsődleges elvárása, hogy megtérüljön az őket ért kár. Ez azonban nem minden esetben következik be. Ha úgy érzik az emberek, hogy nem megfelelö ítélet született az ügyükben, vagy nem sikerül megtalálni az elkövetőt, akkor az az érzés alakul ki az állampolgárokban, hogy nem is érdemes a hatóságokhoz fordulni egy-egy büncselekmény után, hiszen ,úgysem történik semmi”. Az áldozatokkal kapcsolatos kutatások során felszínre került az úgynevezett másodlagos viktimizáció jelensége. A másodlagos viktimizáció esetén a sérelem nem a büncselekmény közvetlen következménye, hanem a sértettekkel a büncselekmény során kapcsolatba kerülő hatóságok, civil szervezetek, egyházak, szakemberek áldozatokhoz való nem megfelelő hozzáállásának, viszonyulásának következménye. „, $A z$ események felidézése, az elkövetővel való szembesités, a hatóságok, bíróságok, ügyészségek és a terhelt védelme részéröl tanúsitott bánásmód igen nagy lelki teherrel járhat, számos esetben megalázó lehet a sértettre. A processzuá- 
lis helyzet meghatározása tehát nem kis mértékben ezeknek a negatívumoknak a kiküszöbölését vagy legalábbis a lehetö legkisebb mértékre csökkentését szolgálja. Ez érdekében áll a sértettnek, de alapvetöen az eljárásnak is, hiszen a cselekmény elszenvedöjének aktivitása jelentös mértékben befolyásolja az ügy elbirálásának folyamatát. A sértettek közül azonban igen sokan nem tesznek feljelentést, ami a törvényes eljárás lefolytatásának meghiúsitása mellett a bünözés valóságának feltárását is neheziti. "” Elsődlegesen a szexuális jellegü büncselekményekkel kapcsolatban lehet jelentős szerepük ezeknek a negatív tapasztalatoknak, de más esetekben is előfordul, hogy az áldozatokat további sérelmek érik az eljárás során. Ezek a tapasztalatok egyértelmüen csökkentik a feljelentési hajlandóságot. A hatóságokba, rendőrségbe vetett bizalom csökkenhet társadalmi és politikai okokból is. Az állampolgárok érzékenyen reagálnak bizonyos társadalmi, politikai változásokra, és amennyiben kedvezőtlennek ítélik azokat, akkor jelentősen csökkenhet a hatóságok iránti bizalom, ennek következtében a feljelentési hajlandóság. A tapasztalat azt mutatja, hogy a diktatúrákban jelentősen alacsonyabb bünözési szintet mutatnak a bünügyi statisztikák, amiben biztosan közrejátszik az is, hogy az emberek még sértettként sem akarnak kapcsolatba kerülni a hatóságokkal.

Konkrét erre irányuló empirikus vizsgálatok hiányában csak közvetett módon következtethetünk arra, hogy hogyan változott a feljelentési hajlandóság. Ez egyik lehetőség a rendőrség által megrendelt közvélemény-kutatások eredményeinek felhasználása. Ezekben nem kérdeznek rá közvetlenül az esetleg megtörtént esetekre, hanem a rendőrséggel, nyomozó hatóságokkal kapcsolatos lakossági attitüdöket igyekeznek felmérni. Ha a bizalmi kérdésekre adott válaszok magas értékeket mutatnak, akkor az elemzők arra következtetnek, hogy jó a kapcsolat a lakossággal, és ez jó feljelentési hajlandóságot teremt. A mért adatok javuló tendenciát mutatnak: 2010-ben még 65, 2017-ben már 78,6 százalékos elégedettséget mértek. Az általános elégedettség azonban nem feltétlenül jár együtt a magas feljelentési hajlandósággal. A rendőrségbe vetett bizalmon kívül még sok tényező befolyásolja a feljelentési hajlandóságot.

Ha bizonyítani tudnánk, hogy a feljelentési hajlandóság nem változott (esetleg javult), akkor a bűnügyi statisztikában jelentkező csökkenő esetszámokat nagyobb valószínüséggel tekinthetnénk a ténylegesen csökkenő törvénysértések eredményének. Az egyébként is szükséges viktimológiai adat-

3 Korinek László: Kriminológia. Magyar Közlöny Lap- és Könyvkiadó, Budapest, 2010, 381-382. o. 
felvételek során könnyüszerrel vizsgálható volna ez a kérdés is, ezek hiányában maradnak a közvetett módszerek. Nézzük meg, a vizsgált időszakban hogyan alakult azoknak a büncselekményeknek a száma, amelyek esetében kisebb jelentősége van a feljelentési hajlandóságnak. Tipikusan ilyenek az erőszakos és garázda jellegü és a közlekedési büncselekmények. Ezeknek az alakulását mutatja a 2. és a 3. számú ábra a vizsgált időszakban.

2. számú ábra

Erőszakos büncselekmények alakulása (2006-2017)

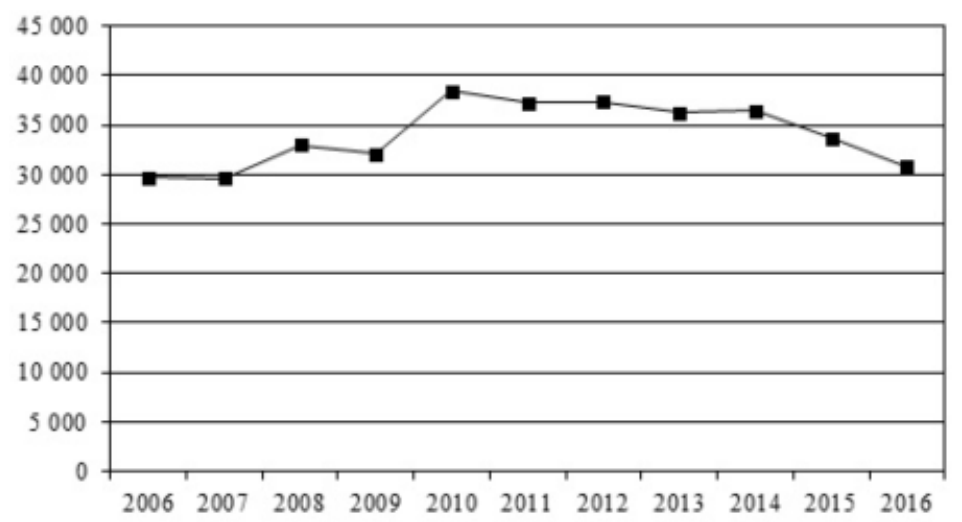

A 2. számú ábrán jól látható, hogy az erőszakos bủncselekmények esetében nyoma sincs az összes regisztrált büncselekmény esetében tapasztalható látványos csökkenésnek. Hasonló a helyzet a közlekedési büncselekmények esetében is (3. számú ábra).

A közlekedési büncselekmények esetében a csökkenő tendencia ellenkezöjét láthatjuk. Az összes ismertté vált büncselekmény esetében jelentős csökkenést mutató 2013-as adatokkal szemben a közlekedési büncselekményeknél növekedést mutatnak az adatok.

A rendőrség bizalmi indexén alapuló hipotézis szerint a lakosság feljelentési hajlandósága nem változott, vagy inkább javult. A regisztrált büncselekmények száma csökkent, akkor valószínüleg azért került be kevesebb eset a nyilvántartásba, mert kevesebb büncselekmény történt. Változatlan feljelentési hányaddal számolva, akkor kevesebb büncselekményt követtek el. A bünözés összességében csökkent, de akkor azoknál a büncselekményeknél is jelentkeznie kellene a csökkenésnek, ahol a feljelentési hajlandóság kevésbé játszik szerepet. A regisztrált erőszakos büncselekmények és a közlekedési büncselekmények száma azonban nem csökkent. Ezek az adatok a feljelenté- 
3. számú ábra

Közlekedési büncselekmények (2006-2017)

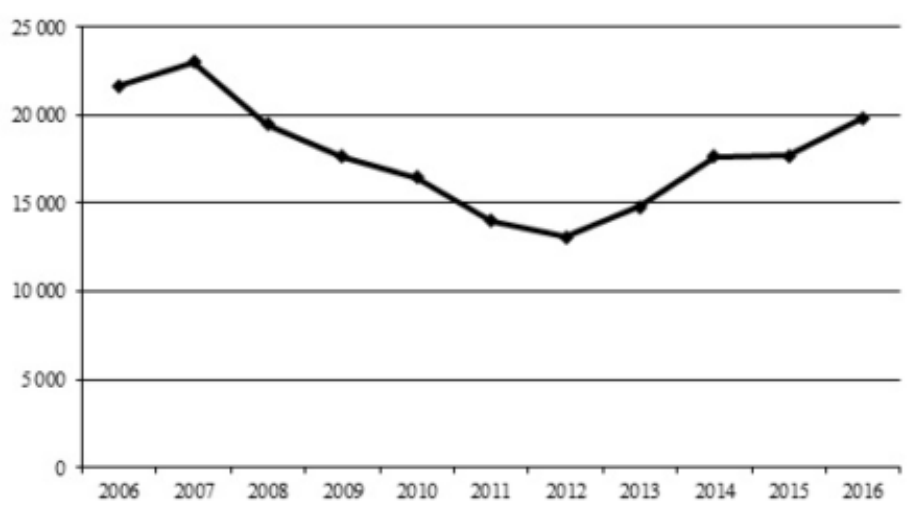

si hajlandóság változatlanságának hipotézise ellen szólnak. Inkább a feljelentési hajlandóság csökkenését valószínüsítik.

Az adatok inkább arra engednek következtetni, hogy nem a bünözés egészében következett be olyan jelentős csökkenés, mint amit a regisztrált esetekről szóló statisztika mutat. Utóbbi lehetőség mellett szól az is, hogy a rendszerváltást követő ugrásszerü emelkedés a regisztrált büncselekmények számában jelentős társadalmi változásokkal kapcsolódott össze. Amennyiben egyetértünk azzal, hogy a bünözés társadalmi jelenség, és a kiváltó okai társadalmi tényezőkre, hatásokra vezethetők vissza, akkor a statisztikában megjelenő jelentős változásoknak, ha a tényleges bünözés alakulását tükrözik, jelentős társadalmi változások következményeként kellene megjelenniük. Az 1990-es években megtaláljuk azokat a társadalmi változásokat, amelyek a növekvő bünözést indukálták. Ha megnézzük, mi okozta annak idején a növekedést, akkor talán választ kaphatunk arra is, hogy most mitöl csökken a regisztrált büncselekmények száma. Azok a tényezők, amelyek a rendszerváltás utáni növekedést okozták, felelhetnek a mostani csökkenésért, csak ellenkező előjellel. Ha a drasztikus növekedésnek megvoltak a társadalmi okai, akkor a jelentős csökkenésnek is meg kellene találnunk a mozgatórugóit. A 2012-2015-ös időszakban azonban nem látszanak ilyen jelentős társadalmi változások. Ebben az esetben inkább annak a feltételezésnek van létjogosultsága, hogy a bünügyi statisztikában bekövetkezett jelentős változások nem a bünözés egészében bekövetkezett csökkenésre vezethetők vissza. Társadalmi változások hiányában más okokat kell találnunk, amelyek megmagyarázzák a nagymérvü csökkenést. 


\section{A nyomozó hatóságok preferenciái}

Az ENYÜBS elsősorban ügyforgalmi statisztika. Azokat az ügyeket tartalmazza, amelyekben a nyomozó hatóság valamilyen eljárást lefolytatott.

Szokták azt a kifejezést használni, hogy a hatóságok tudomására jutó eseteket tartalmazza, de sajnos ez sem teljesen pontos. A nyomozó hatóságok esetében ugyanis müködnek úgynevezett elhárító mechanizmusok, amelyek segítségével az eleve reménytelennek vagy bagatellnek gondolt eseteket kiszürik a rendszerből, és ezek meg sem jelenek a statisztikában, holott a hatóság foglalkozott az üggyel, csak nem tartotta kivizsgálásra érdemesnek. Ilyen kiskaput jelentenek hazánkban a szabálysértések. Amennyiben az adott cselekmény nem büncselekmény, hanem szabálysértés, akkor a nyomozó hatóság mentesül a további teendők alól, és nem kell foglalkoznia az üggyel. Így, ha például valaki bejelenti a rendőrségen, hogy ellopták a kabátját, akkor a következő párbeszédre számíthat: - Mennyibe került? - Hatvanötezer forintért vettem két éve. - Akkor az már nem ér csak legfeljebb harmincezer forintot. - Tulajdonképpen igaza van.

Az ügy megoldva. Szabálysértés történt, további teendők nincsenek, az eset nem kerül be a bünügyi statisztikába ${ }^{4}$.

Sajnos még mindig használatos a bünügyi statisztika a nyomozó hatóságoknál az egyes egységek teljesítményértékelésére. Ez a súlyos probléma végigkíséri az ERÜBS-ENYÜBS rendszer működését, amelytől a kezdetektől próbál megszabadulni, de nem sikerül neki. A rendőrség egészének és az egyes rendőri szerveknek a munkáját elsősorban a statisztikai adatok felhasználásával értékelik.

Már régen megfogalmazódott, hogy törekedni kell a rendőri munka értékelésének és a statisztikai nyilvántartási rendszernek a szétválasztására. A rendőri munka értékelése jelentős mértékben támaszkodik még ma is az ENYÜBS rendszerben is megjelenő statisztikai, nyomozáseredményességi mutatókra. Ezzel az a probléma, hogy egy olyan rendszer adatai alapján ítélik meg a nyomozó hatóságok egyes egységeinek munkáját, amelyet ők maguk állítanak elö. Ezzel kapcsolatban Vavró István 2002-ben még óvatosan fogalmazott: , A kriminálstatisztika részét képezik azok az adatok is, amelyek a bünüldözö, jogalkalmazó szervek tevékenységére vonatkoznak. Ezeknek a szerveknek a tevékenysége ad ugyanis lehetöséget a bünözés megismerésére. 4 Természetesen a nyomozó hatóságok szabálysértési ügyekhez kapcsolódóan is végeznek feladatokat,
akár előállításra is sor kerülhet, de ezek az eljárások a bünügyi statisztika alakulását nem érintik. 
Ezzel kapcsolatban azonban nem hagyható figyelmen kivül, hogy itt bizonyos teljesitmények mérésére is sor kerül. Emberileg ezért teljesen érthetö, ha az adatszolgáltatók »megfelelö körültekintéssel « járnak el akkor, amikor a tevékenységükre vonatkozó adatokat összeállitják. "'

Az egyes nyomozó szerveknek és a nyomozást végzőknek maguknak kell előállítaniuk azokat a statisztikai adatokat, amelyek felhasználásával a munkájukat értékelik. Adott a lehetőség és a motiváció az adatok kisebb-nagyobb mértékű korrigálására, manipulálására. Amennyiben a rendőrök tudják, hogy munkájukat az általuk kitöltött adatlapok alapján értékelik, akarva vagy akaratlanul, de torzíthatják a statisztikai adatokat. Erre a közelmúltban is akadt néhány példa.

„A gödöllöi és a III. kerületi kapitányságon történt statisztika-hamisitás miatt tett feljelentést Hatala József országos rendörfökapitány. Kovács Tamás volt legföbb ügyész a Pintér Sándor belügyminiszternek cimzett tavaly nyári levelében a büntetöjogi felelösségre vonást elkerülhetetlennek tartotta a hamis statisztikai adatszolgáltatás miatt."

Egyes kapitányságok a kedvezőbb év végi értékelés érdekében visszatartottak felderítetlen ügyeket. Elöfordul, hogy az eleve reménytelennek ítélt ügyeket még a nyomozás korai szakaszában a hatóságok valamilyen módszerrel igyekeznek elhárítani. A nyomozó hatóságok az eredményes ügyek részarányának növelésében érdekeltek, éppen ezért sokféle módszert fejlesztettek ki és alkalmaznak a reménytelen ügyek elhárítására. A kisebb súlyú vagyon elleni cselekményeknél a leggyakoribb módszer a szabálysértési értékhatár rugalmas kezelése. Amennyiben sikerül az okozott kár becsült értékét az értékhatár alatt tartani, máris megszabadultak egy esettől, ami immár nem büncselekmény, hanem szabálysértés, így nem kerül be és nem rontja a statisztikát.

„A bünügyi statisztika manipulálásának kifinomult módszerei alakultak ki az idök folyamán. Gyakran egy ügyszámra tettek két olyan ügyet, amelyben nem volt várható sikeres felderités. Ha nehéznek igérkezett a felderités, a rendör inkább bejelentést javasolt feljelentés helyett, mert az igy nem került be a bünügyi statisztikába. Ugyanakkor bekerült a bünügyi adatok közé, ha az eljárást érdemi nyomozati cselekmény nélkül függesztették fel, de nem számitott bele sem az eredményes, sem az eredménytelen ügyek közé. Egy nevének elhallgatását kérő volt rendőr beszámolója szerint egy új kapitányságve-

5 Vavró István: A kriminálstatisztika és a bűnözés valósága. Kriminológiai Közlemények. Magyar Kriminológiai Társaság, Budapest, 2002, 17. o.

6 Gödöllőn és Óbudán meghamisították a bünügyi statisztikát. HVG.hu, 2011. március 10. 
zetö a váltást követöen szinte azonnal razziára küldte őket a helyi bolhapiac$r a$, ahol több száz másolt DVD-t foglaltak le. Minden adathordozót külön ügynek vették, így több száz statisztikai lapot töltöttek ki, noha csak egyetlen cselekményröl volt szó. A kapitányságvezetö egy csapásra jelentösen javitott a felderitett ügyek számán, és egyúttal bizonyitotta, hogy jó választás volt." "7

„,Országos vizsgálatot inditott a Legföbb Ügyészség annak megállapitására, hogy pontosan milyen mértékben kozmetikázták a rendörök az egységes nyomozóhatósági és ügyészségi büntetö-statisztikát. A vizsgálat tizezres nagyságrendben tárt fel hibákat, hiányosságokat, szándékos torzitásokat. Az évi 400 ezerhez közeli büncselekményszám mellett ilyen mennyiségü valótlan adat már a statisztika egészének a hitelességét kérdöjelezi meg. "\$

Ilyen messzemenö következtetést talán még nem kell levonnunk, de a probléma jelen van a bünügyi adatszolgáltatási rendszerben.

Segíthet a helyzet objektív megítélésében, ha a nyomozáseredményességi mutató helyett az ismertté vált elkövetők számának alakulását vizsgáljuk (4. számú ábra). A nyomozáseredményességi mutató ugyanis nagyon érzékeny az összes regisztrált büncselekmény számának alakulására. Amennyiben kevesebb eset jelenik meg a statisztikában, minden más tényezőtől, például a tényleges munkavégzéstől függetlenül, javuló arányszámokat kapunk. Az ismertté vált bünelkövetök száma jobban tükrözi a nyomozó hatóságok munkájának eredményességét, mert csak a tényleges eredményeket mutatja, hogy ezek mellett hány olyan esettel kellett foglalkozni, amelyekben nem sikerült megtalálni az elkövetőt, az a leterheltségröl adhat információt. S ebben az esetben, ha több ilyen ügy van, akkor több esettel kellett foglalkozniuk a nyomozó hatóságoknak, a csökkenő összes regisztrált cselekmény pedig kisebb leterhelésről tanúskodik.

Az összes regisztrált büncselekmény számában bekövetkezett 2013-as jelentős csökkenés semmilyen hatással nem volt az ismertté vált bünelkövetők számának alakulására. Lényegében ugyanannyi bünesetet oldottak meg a nyomozó hatóságok, mint korábban, inkább kisebb mértékü csökkenés mutatkozik az adatokban.

Ugyanakkor a rendőrség létszáma folyamatosan emelkedett a vizsgált időszakban (5. számú ábra). A 2010-es adatokhoz viszonyítva mintegy tizenöt-húsz százalékkal több rendőr van szolgálatban. Igaz, a létszámnövekedés nem érintette a bünügyi szolgálati ágat, ott lényegében 2002-től azonos lét-

7 Sereg András: Hazug számok. Jogi Fórum, 2015. január 16. http://www.jogiforum.hu/hirek/33121

8 Ihárosi Ibolya: Durván megugrott a büncselekmények száma. Teol.hu, 2011. április 11.

https://www.teol.hu/tolna/kozelet-tolna/durvan-megugrott-a-buncselekmenyek-szama-370579/ 
4. számú ábra

Ismertté vált bünelkövetők (2006-2017)

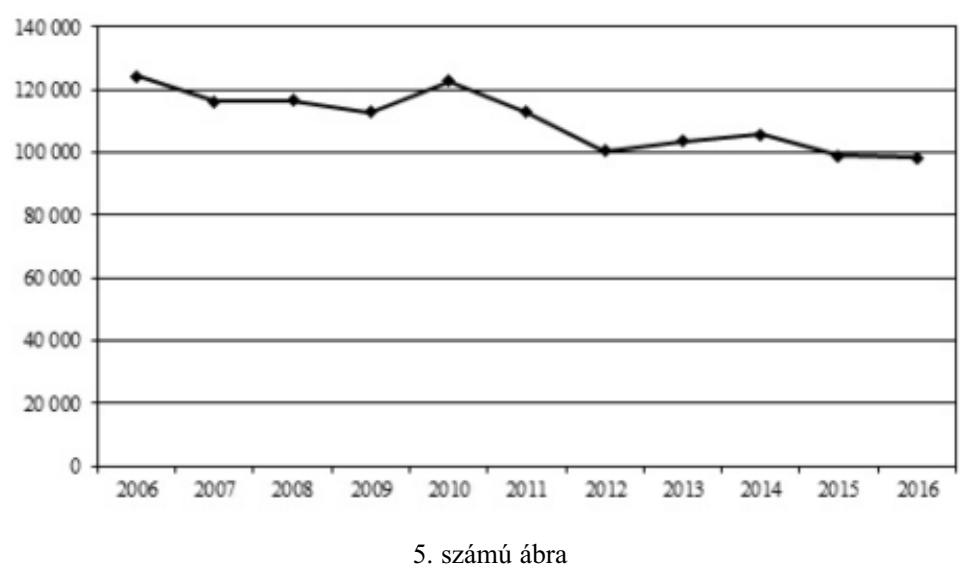

A rendőrség foglalkoztatotti" létszámának alakulása (2010. január 1. - 2017. november 1.)

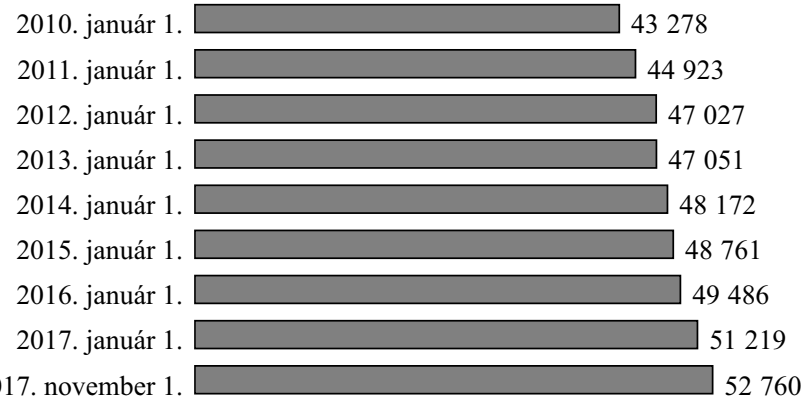

* Tartalmazza a rendelkezési (TEK, NVSZ, TIBEK, RSZG-k és más szervek állományába vezényelteket, továbbá a gyesen, gyeden, illetménynélküli szabadságon stb. tartózkodókat) és a passzív állományt.

számú rendőr látja el a feladatokat, attól függetlenül, hogy kétszáz- vagy négyszázezer esettel kell-e megbirkózniuk.

\section{A jogszabályi környezet alakulása}

Azok a cselekmények számítanak büncselekménynek, amelyek szerepelnek a büntető törvénykönyvben. A büntetőjogi törvények határozzák meg a büncselekmények körét, ha változnak a törvények, változik az elkövetett büncselekmények száma is. A dekriminalizálás értelemszerűen csökkenti a bűncse- 
lekmények számát. A korábban büncselekménynek számító esetek a továbbiakban nem szerepelnek a statisztikában. Amennyiben új tényállások kerülnek be a Btk.-ba, akkor növekszik a törvénysértések száma. A törvénymódosítások valamilyen irányba befolyásolják az elkövetett büncselekmények számának alakulását. A 2013. július 1-jén hatályba lépő új büntető törvénykönyv tartalmaz egy olyan módosítást, ami jelentősen befolyásolta a regisztrált büncselekmények számának alakulását. Ez a módosítás az okirattal visszaélés törvényi tényállását érintette (táblázat).

Regisztrált okirattal visszaélés büncselekmények (2010-2016)

\begin{tabular}{|l|r|r|r|r|r|r|r|}
\cline { 2 - 8 } \multicolumn{1}{c|}{} & 2010 & 2011 & 2012 & 2013 & 2014 & 2015 & 2016 \\
\hline Visszaélés okirattal 277. § (régi Btk.) & 39110 & 58067 & 83881 & 14233 & 706 & 146 & 42 \\
Okirattal visszaélés 346. § (új Btk.) & - & - & - & 636 & 1654 & 3228 & 1221 \\
Összesen & 39110 & 58067 & 83881 & 14869 & 2360 & 3374 & 1263 \\
\hline
\end{tabular}

Forrás: ENYÜBS

Az adatok azt mutatják, hogy 2012-ig az okirattal visszaélések jelentős számban fordultak elő, a törvénymódosítást követően azonban a korábbi számok töredéke jelenik csak meg a statisztikában. Ez az egy törvénymódosítás mintegy évi hatvan-hetvenezerrel csökkentette a regisztrált büncselekmények számát anélkül, hogy bármilyen változás következett volna be a bünözés egészében.

Jelentősen befolyásolhatja a regisztrált büncselekmények számát a szabálysértési értékhatár módosítása is. A leggyakoribb büncselekmény a kisebb értékre elkövetett lopás. Az értékhatár változása számos vagyon elleni cselekmény megítélését befolyásolja. A legutóbbi módosítás (2012. évi C. törvény) 2013. július 1-jén lépett hatályba. Ezzel az addig érvényes húszezer forintos értékhatárt ötvenezer forintra emelték. Az értékhatár ilyen jelentős módosítására még nem került sor korábban. A módosítás következtében az ötvenezer forintnál kisebb értékre elkövetett vagyon elleni cselekmények kikerültek a bünügyi statisztikából, hiszen a statisztika csak a büncselekményeket veszi számba. A bünügyi jellegü szabálysértésekről sajnos nem készül országos összesített statisztika, így a szabálysértések számának alakulásáról nincs információnk. Az intézkedés következtében a korábbi években a bünügyi statisztikában megjelenő nagyjából hatvanezer büncselekmény már nem szerepel a bünözési adatok között. Ez a módosítás tehát körülbelül évi hatvanezerrel csökkentette a regisztrált büncselekmények számát. A hatás nem azonnal jelentkezett, mert a módosítás 2013. július 1-jén lépett hatályba, tehát az év el- 
ső felében még a régi szabályozás volt érvényben, így a csökkenésnek csak körülbelül a fele érvényesült 2013-ban. A normaszegések száma feltehetően nem változott az értékhatár módosítása miatt, de a bünügyi statisztika kevesebb esetet regisztrált.

\section{Nemzetközi összehasonlítás}

Az Európai Unió 28 tagállamában nyilvántartásba vett büncselekmények száma 2003 óta stabilan csökken, 2012-ben 12 százalékkal kevesebb büncselekményt rögzítettek, mint kilenc évvel korábban.

Az elmúlt években általános tendenciává vált a nyilvántartásba vett büncselekmények számának csökkenése: az unió országaiban a rendőrség által nyilvántartott büncselekmény-kategóriák többsége esetében 2007 és 2012 között csökkent a bejelentett esetek száma (6. számú ábra).

$$
\text { 6. számú ábra }
$$

Nyilvántartásba vett büncselekmények száma a 28 uniós tagállamban (2002-2012)

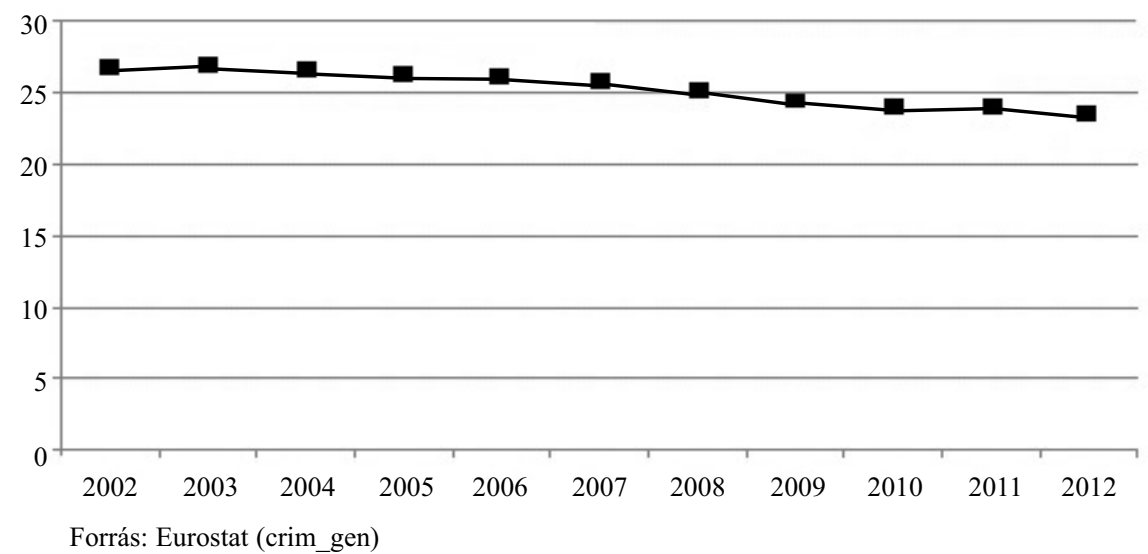

Németországban a Welt am Sonntag által ismertetett, statisztikák szerint 2017-ben 9,6 százalékkal kevesebb büncselekményt regisztráltak, mint egy évvel korábban, összesen 5,76 milliót. Visszaesett a lopások (11,8 százalékkal), a betörések (23 százalékkal), a zsebelések (22,7 százalékkal) és az erőszakos bűncselekmények (2,4 százalékkal) száma is, és kevesebb autónak, illetve biciklinek is kelt lába, mint 2016-ban (8,6, illetve 9,8 százalékkal). 
Ami viszont emelkedett némiképp, az a gyilkosságok száma (3,2 százalékkal, összesen 785 történt 2016-ban), míg a kábítószerrel kapcsolatos büncselekmények száma 9,2 százalékkal csökkent. A nem németek által elkövetett büncselekmények száma összesen 22 százalékkal csökkent tavaly, ami Oliver Malchow, a német rendőrségi szakszervezet vezetöje szerint annak is lehet a következménye, hogy 2017-ben kevesebb bevándorló érkezett az országba. Malchow egyelőre nem szeretne komolyabb következtetéseket levonni a statisztikákból, de az szerinte is figyelemre méltó, hogy ilyen szintü statisztikai javulásra 1993 óta nem volt példa az országban. ${ }^{9}$

A nemzetközi adatokat vizsgálva azt állapíthatjuk meg, hogy lényegében megtört a második világháború óta tartó lassú növekedési tendencia, és az ezredforduló óta a regisztrált bủncselekmények száma a legtöbb európai országban csökkenést mutat. A csökkenés nem olyan drámai, mint Magyarországon, de tartós csökkenő tendencia rajzolódik ki az adatokból. Magyarország is az Európai Unió tagja és valószínüleg nem vonhatja ki magát az általános tendencia alól. A nálunk is tapasztalható csökkenés egy része (tíz-tizenöt százalék) a nemzetközileg érvényesülő tendencia számlájára írható. A lényeges különbséget a csökkenés mértéke jelenti. Az európai országok többségében a csökkenés évi öt-tíz százalék.

\section{A vétőképes korú lakosság}

Még egy lényeges tényezőt meg kell vizsgálnunk a regisztrált büncselekmények jelentős csökkenésével kapcsolatban, s ez a vétőképes korú lakosság számának változása az ország népességében. Vavró István több tanulmányában is elemezte az egyes kohorszok létszámában bekövetkezett változások és a regisztrált büncselekmények számának alakulása közötti kapcsolatot. Rámutatott, hogy az alacsonyabb születési számmal és létszámmal jellemezhető kohorszok vétőképes korúvá válása kimutatható változást okozott a regisztrált büncselekmények számában.

Akár hatszázezernél is több magyar élhet jelenleg az Európai Unióban, ez a szám lényegesen magasabb a korábbi becsléseknél - derül ki a Portfolio.hu összesítéséből ${ }^{10}$. A legtöbben hivatalosan Németországban élnek, de még Dániában is több mint ötezer magyar munkavállaló él tartósan (7. számú ábra).

\footnotetext{
9 Polizeilichen Kriminalstatistik (PKS), 2017.

10 https://www.portfolio.hu/gazdasag/mar-tobb-mint-600-ezer-magyar-elhet-europaban-2019-is-kivandorlo-ev-lesz.308543.html
} 
Az EU-tagállamokban élő magyarok száma

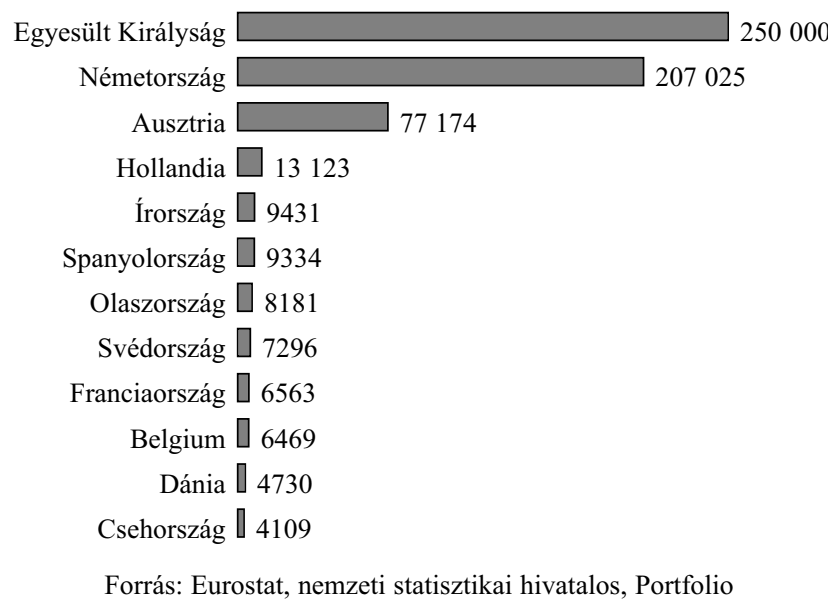

Vavró István a születési arányszámokban bekövetkezett változásoknak a bünözés alakulására való hatását vizsgálva ${ }^{11}$ arra a következtetésre jutott, hogy: „Azokban az idöszakokban ugyanis, amikor a bünözés szempontjából domináns korosztályok össznépességen belüli aránya emelkedik, a bünözés volumene változatlan korspecifikus bünözési gyakoriság mellett is nö. "I2 Nyilván a fordított összefüggés is igaz lehet: ha a vétőképes korú lakosság, illetve a bünözésben domináns korosztályok létszáma csökken, akkor az összbünözésben is csökkenést fogunk tapasztalni. A Vavró által vizsgált születési arányszámokban ötven-hatvanezres különbségek voltak. Ha néhány tízezres eltérés a releváns korosztályokban kimutatható különbségeket okoz a bünözés egészében, akkor a jelenleg tapasztalható kivándorlási hullám is hatást kell hogy gyakoroljon a bünözés alakulására, hiszen most több százezres különbség tapasztalható. Ha megvizsgáljuk a külföldön élök kor szerinti megoszlását, azt láthatjuk, hogy a bünözés által leginkább érintett korosztályokból kerül ki a külföldön élők többsége (8. számú ábra) ${ }^{13}$.

A németországi kormegoszlás jó kiindulópont lehet az összes külföldön élő magyar korösszetételének vizsgálatához. A külföldön élők és a bűnelkövetők

\footnotetext{
11 Vavró István: A demográfiai-társadalmi tényezők és a bűnözés kapcsolata. Statisztikai Szemle, $1994 / 1$.

12 Uo. 38. o.

13 https://www.portfolio.hu/gazdasag/megmutatjuk-miert-tragedia-a-kivandorlasmagyarorszagnak.261319.html
} 


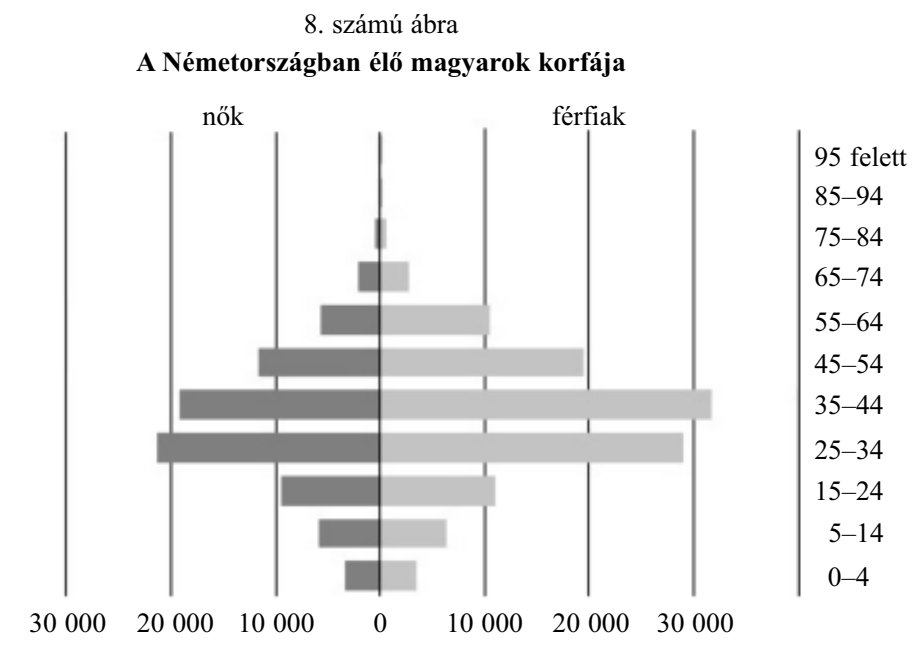

kormegoszlása nagyon hasonló képet mutat. Tételezzük fel, hogy az itthon maradók és a külföldre távozók között ugyanolyan arányban fordulnak elö törvénysértést elkövetők, akkor a százezer lakosra jutó büncselekményi arányszámok alapján közelítő becslést adhatunk arra vonatkozóan, menyivel csökkentheti a Magyarországon regisztrált büncselekmények számát a külföldre távozott hatszázezer ember. A becslés meglehetősen bizonytalan, mert attól is függ, hogy milyen gyakoriságokkal számolunk, melyik időszakot vesszük figyelembe stb. Közelítőleg tizennégy- és harmincezer közötti regisztrált büncselekményről lehet szó. Körülbelül ennyivel csökkenhet a regisztrált büncselekmények száma a kivándorlás következtében. A pontos számadat vitatható, de valamekkora csökkenést biztosan előidéz a kivándorlás.

\section{Összegzés}

Megvizsgálva a 2013-tól erőteljesen csökkenő regisztrált büncselekményszámok mögött rejlő okokat, az a következtetés adódik, hogy több tényezőre vezethető vissza az esetszámok csökkenése. Elsődlegesen és legnagyobb mértékben a törvényi szabályozás változása játszott szerepet az új trend kialakulásában. Az okirattal visszaélés és a szabálysértési értékhatárt módosító törvények következtében száz-százhúszezerrel csökkent a regisztrált büncselekmények száma. Ez a csökkenés csak a statisztikát érintette, és valószínűleg 
nem okozott változást a ténylegesen elkövetett szabályszegések gyakoriságában. Kisebb mértékben, de társadalmi hatások, jelenségek is a csökkenés irányába hatottak az elmúlt időszakban. Az ezredforduló óta általános nemzetközi jelenség a regisztrált büncselekmények számának csökkenése. Az Európai Unió tagállamaiban és a fejlett ipari országokban enyhén csökkenő tendencia mutatható ki. Valószínüleg Magyarországon jelentkezik ennek a nemzetközi tendenciának a hatása. Az érintett országokban a csökkenés az ezredforduló óta 15-25 százalék volt az elmúlt tíz-tizenöt évben. Ha ez a tendencia érvényesül nálunk is, akkor ez körülbelül hatvanezres esetszámcsökkenést jelenthet.

A feljelentési hajlandóság alakulásáról nincsenek közvetlen információink, de a kevésbé érintett büncselekmények gyakoriságának vizsgálata alapján az valószínűsíthető, hogy valamelyest csökkent az elmúlt években. A csökkenés mértéke nehezen volna számszerüsíthető célzott vizsgálatok hiányában.

A munkaerő és a lakosság erőteljes kivándorlása is hozzájárult a regisztrált büncselekmények számának mérséklődéséhez, s ez esetben a ténylegesen elkövetett cselekmények, azaz a látens büncselekmények száma is csökkenhetett.

Összességében adminisztratív és társadalmi változások együttes eredőjének tekinthető a hazai bünügyi statisztikában korábban soha sem tapasztalt erőteljes csökkenés.

\section{FELHASZNÁLT IRODALOM}

Ducato, Marco (ed.): The crime against businesses in Europe: Pilot survey. 2010/ISEC/Pr/042-A2

Kertész Imre: A bűnözés társadalmi háttere. Jogtudományi Közlöny, 1981/2.

Kertész Imre - Zvekic Ugljesa: Büncselekmények áldozatai a rendszerváltás országaiban. Nemzetközi vizsgálat eredményei. BM Kiadó, Budapest, 2000

Korinek László: Kriminológia Magyar Közlöny Lap- és Könyvkiadó, Budapest, 2010

Sereg András: Hazug számok. Jogi Fórum, 2015. január 16.

http://www.jogiforum.hu/hirek/33121

Tauber István: Gazdasági, társadalmi viszonyok változása és a bünözés alakulása In: Tények és kilátások. KJK. Budapest, 1995

Vavró István: A demográfiai - társadalmi tényezők és a bünözés kapcsolata. Statisztikai Szemle, 1994/1.

Vavró István: A kriminálstatisztika és a bűnözés valósága. Kriminológiai Közlemények. Magyar Kriminológiai Társaság, Budapest, 2002

Vavró István: A kriminológiai és a büntetőjogi büntett fogalom néhány kérdése. Belügyi Szemle, 1969/7.

Vavró István: Iskolai végzettség, társadalmi helyzet, bűnözés. Statisztikai Szemle, 1986/3. 